designed $1000 \mathrm{MW}$ plant. The demonstration was the largest in Finland since the anti-Vietnam war demonstrations of the late 1970 s. Finnish environmentalists are demanding that the contract between the state-owned Imatra Voima company and the Soviet export organisations, Atomenergoexport and all other future nuclear decisions be subjected to full parliamentary debate.

- Dutch police arrested 29 anti-nuclear demonstrators who chained themselves to the gates of the Borssele nuclear plant in Zeeland last week. The protest prevented two changes of shift at the nuclear facility. A total of 150 demonstrators, members of the Dutch anti-nuclear group "Break the Netherlands Atomic Chain"' padlocked all seven gates at the plant, preventing entrance for 20 hours until their arrest and dispersal by police.

- In Britain, a second Scottish local authority has refused planning permission for test site waste disposal drilling. The Atomic Energy Authority has asked for another public inquiry to be held to try to obtain permission to drill 32 boreholes near Loch Doon, south west Scotland after its proposal was rejected by the Kyle and Carrick county council. The Conservativecontrolled council feared that if granted, the proposal would lead to a detailed application for a demonstration disposal plant.

According to figures released by the Secretary of State for the Environment in parliament recently, the UK civil and military nuclear programmes produce $100 \mathrm{~m}^{3}$ of high level liquid wastes, $500 \mathrm{~m}^{3}$ high level solid wastes, $450 \mathrm{~m}^{3}$ plutonium contaminated waste and $250 \mathrm{~m}^{3}$ miscellaneous waste each year. Some medium and low activity wastes including plutonium-contaminated material and reactor decommissioning wastes are dumped at sea.

The total waste stored at civil nuclear power stations at the end of 1979 was $20,000 \mathrm{~m}^{3}$. Of this, the total accumulation of high level liquid waste was $1,000 \mathrm{~m}^{3}$ at Windscale from the reprocessing of power reactor fuel and $700 \mathrm{~m}^{3}$ at Dounreay from the reprocessing of fuel from experimental reactors. In addition, approximately $9,000 \mathrm{~m}^{3}$ of high level solid waste and $3,500 \mathrm{~m}^{3}$ of plutonium-contaminated waste are in store. The total accumulation at AEA and British Nuclear Fuel sites of medium level liquid wastes, concentrates, sludges and resins, wastes from decommissioning reactors and other plant and other medium level wastes is about $11,000 \mathrm{~m}^{3}$.

The National Radiation Protection Board has spent $£ 70,000$ since 1977 to assess the radiological consequences of disposing of radioactive waste in geological formations.

Joe Schwartz

EEC

Melt-down experiment go-ahead

FrANCE has removed its objections to an experiment simulating the melt-down of a nuclear reator, and so removed the last obstacle to the European Community's $£ 530$ million, 1979-83 programme for fusion research and support of the Joint Research Centre at Ispra, North Italy.

Italy, as part of its diplomatic activity over European research (3 January, page 3) had refused to endorse the budget of the EEC's fusion programme until France accepted the meltdown experiment, which is now to take place between 1983 and 1986 in the reactor Essor at Ispra. experiment at Cadarache, but, says $\mathrm{Mr}$ Tom Doyle, head of Essor division, "Cadarache has only half the dimensions of ours" and the scale of the experiment substantially affects the results.

The US exerted pressure for the Essor experiment - called 'Super-SARA' - to be undertaken as a next step from similar, smaller tests which have been performed on the Power Burst Facility at Idaho. According to a 1979 Nuclear Regulatory Commission report Super-SARA should provide more information on melt-down than any other planned experiment.

"Essor is a heavy water reactor" Mr Doyle
France was planning its own similar

told Nature; "the active core is 1.5 metres high, compared to a typical research reactor's 0.8 metres." Moreover there are enough channels to make simultaneous tests on 36 fuel rods (compared to 16 at Idaho).

Super-SARA will consist of 20 experiments to simulate loss of coolant in a light water reactor either rapidly, over 10-20 minutes, or more slowly (the 'small break' case as at Three Mile Island). Fuel rods will be taken to the rupture of cladding, but it is intended to leave the rest of the reactor unaffected. This is "a bit of a difficult problem" says Doyle, but not insurmountable.

The experiments are necessary, he says, because calculations are very difficult: "you have a two-phase problem under transient conditions".

The successful flurry of diplomatic activity between Italy and France over Super-SARA began last December, when the EEC Council of Energy Ministers was faced with a French veto. The French High Commissioner for Atomic Energy in the case was Jean Teillac who, as President of the Council of the European sub-nuclear physics organisation, CERN, was resisting Italian moves to 'clarify' CERN's future.

Robert Walgate

\section{UK attacks mercury directive}

THE latest draft environmental directive issued by the European Commission in Brussels concerns mercury emitted into rivers by the chlor-alkali industry - and it has come in for the now familiar sharp attack from the UK House of Lords subcommittee on the environment.

In a report published last week, the subcommittee charges that the EEC directive should not confine itself to one industry (there are other sources of mercury), should deal separately with solid and soluble mercury, and should not specify limits without indicating whether an absolute maximum or some kind of average is intended. Moreover, some of the limits are unduly stringent, says the report.

However, Britain emits more mercury into its rivers than any other EEC country, when the figures are related to chlorine production: $16.9 \mathrm{~g}$ per tonne of chlorine compared, say, to $3 \mathrm{~g}$ per tonne in France.

But the basic difference between the Lords and Brussels is over the difference between "environmental quality objectives" (EQOs) as usually adopted for water in Britain, and the "emission standards" favoured by other EEC members. Although Britain has convinced the Commission to establish both for each

'Water pollution: mercury' House of Lords Session 1979-80 38th report of the Select Committee on the European communities. HMSO. new pollutant considered (mercury is the second, after aldrin, dieldrin, and endrin, and cadmium will be next) the philosophies of the two are too different for them to sit easily together.

EQOs are easiest to establish where the control of river catchment areas is unified, as it is through the water authorities in the UK, and water use, defining necassary. quality, a national matter. But in continental Europe rivers such as the Rhine are far from such unification.

"The apprehensions of member states subject to cross-frontier pollution" says the report "rest partly on the fact that an upstream member choosing the EQO alternative route could adopt a water use requiring less stringent standards than a neighbouring downstream member state obliged to use the water for purposes ... which would demand higher standards"'.

Britain and the rest of the community are thus likely to have continuing difficulties over environmental standards; and these are accentuated by the greater scientific rigour required when setting EQOs as opposed to emission standards. "It is clear" says the House of Lords report "that the Commission has too few staff available to work on environmental proposals . . . For example, there is no expert on toxicology." The House of Lords will debate the report on 17 April 1980.

Robert Walgate 